\title{
Fauna of Leptophlebiidae Banks (Insecta: Ephemeroptera) on fragments of the Atlantic Forest from west region of Santa Catarina State, Brazil
}

\author{
Erikcsen Augusto Raimundi', Frederico Falcão Salles ${ }^{2}$ \& Gilza Maria de Souza-Franco ${ }^{1,3}$ \\ ${ }^{1}$ Universidade Comunitária da Região de Chapecó - UNOCHAPECÓ, \\ Av. Senador Attílio Fontana, 591-E, Efapi, CEP 89809-000, Chapecó, SC, Brasil. www.unochapeco.edu.br \\ ${ }^{2}$ Universidade Federal do Espírito Santo - UFES, Rod. BR 101 Norte, Km 60, Litorâneo, \\ CEP 29932-540, São Mateus, ES, Brasil. www.ufes.br \\ ${ }^{3}$ Corresponding author: Gilza Maria de Souza-Franco,e-mail: gfranco@unochapeco.edu.br
}

RAIMUNDI, E.A., SALLES, F.F. \& SOUZA-FRANCO, G.M. Fauna of Leptophlebiidae Banks (Insecta: Ephemeroptera) on fragments of the Atlantic Forest from west region of Santa Catarina State, Brazil. Biota Neotrop. 13(4): http://www.biotaneotropica.org.br/v13n4/en/abstract?article+bn01013042013

Abstract: The first studies of Leptophlebiidae in the Santa Catarina State, Southern Brazil, dated from 1920. Since then, not much is known about the family (even to the Order Ephemeroptera) to the State. The main goal of this study was to survey fauna of Leptophlebiidae in the Santa Catarina State based on nymphs. The material was obtained from the collection deposited at the Laboratório de Pesquisa em Ecologia e Química of the Universidade Comunitária da Região de Chapecó, besides additional specimens collected between 2008 and 2009. Occurrences were plotted in the hydrograph map of Santa Catarina State, with one map for each genus. The Leptophlebiidae nymphs were recorded in 26 aquatic environments that included small streams and rivers. We identified 24 morphotypes distributed in 12 genera. Number of genera in the Western of Santa Catarina increased from eight to 15. Thraulodes, Ulmeritoides and Homothraulus presented higher frequency of occurrence in the region. Leentvaaria and Hermanella were associated to regions well conserved such as in the Araucaria forest. Needhamella and Segesta were related mainly to Irani River.

Keywords: Atalophlebiinae, Uruguai River, Brazilian Southern, nymphal stage, survey.

RAIMUNDI, E.A., SALLES, F.F. \& SOUZA-FRANCO, G.M. Fauna de Leptophlebiidae Banks (Insecta: Ephemeroptera) em fragmentos de Mata Atlântica no oeste de Santa Catarina, Brasil. Biota Neotrop. 13(4): http://www.biotaneotropica.org.br/v13n4/pt/abstract?article+bn01013042013

Resumo: Os primeiros estudos de Leptophlebiidae em Santa Catarina, Sul do Brasil, datam de 1920. Desde então, pouca informação foi acrescida à Família (até mesmo à Ordem Ephemeroptera) para o estado. O objetivo deste estudo foi inventariar a fauna de Leptophlebiidae no Estado de Santa Catarina com base em ninfas. Os Leptophlebiidae foram obtidos através de coleção depositada no Laboratório de Pesquisa em Química e Ecologia da Universidade Comunitária da Região de Chapecó além de espécimes adicionais coletados entre 2008 e 2009. As ocorrências foram plotadas no mapa hidrográfico do Estado de Santa Catarina, com um mapa para cada gênero. As ninfas Leptophlebiidae foram registradas em 26 ambientes aquáticos que incluiram pequenos riachos e rios. Foram identificados 24 morfotipos distribuídos em 12 gêneros. O número de gêneros no Oeste de Santa Catarina aumentou de oito para 15. Thraulodes, Ulmeritoides e Homothraulus foram os gêneros com maior frequência de ocorrência na região. Leentvaaria e Hermanella estiveram associados a regiões mais bem conservadas, como na floresta Ombrófila Mista. Needhamella e Segesta estiveram relacionados principalmente ao rio Irani. Palavras-chave: Atalophlebiinae, Rio Uruguai, Região Sul brasileira, estágio ninfal, levantamento. 


\section{Introduction}

Santa Catarina State was covered by $100 \%$ of Atlantic Forest, but $23.39 \%$ remains in conserved areas (SOS Mata Atlantica \& Instituto... 2009). There are four forest formations in the State: Mixed Ombrophilous Forest, Dense Ombrophilous Forest, High-elevation grassland (or savannah of grass-woody) and, Decidual Forest (SOS Mata Atlantica \& Instituto... 2009). Likewise, there are other vegetal formations, such as sandbank's vegetation and, mangrove's vegetation, which can be closely found to littoral region.

The fast process of deforestation in Santa Catarina State has also compromised quality and availability of aquatic resources. Ally to poor knowledge about its aquatic biodiversity, hydrographic regions such Alto Rio Uruguai (the largest hydrographic region of western Santa Catarina), is considered one of those priorities areas for environmental conservation in Brazil (Brasil 2006).

Leptophlebiidae is one of the richest families of Ephemeroptera in the world, as well as in the Neotropical and Southern America regions, especially when it comes to the generic level (Tsui \& Peters 1975; Domínguez et al. 2001, Barber-James et al. 2008). This highest richness is also accompanied by high number of endemic taxa (Barber-James et al. 2008).

Taxonomic knowledge of Leptophlebiidae in Brazil is still incipient (Salles et al. 2004). Yet, ecological and biological aspects are fragmented in papers on benthic macroinvertebrates (e.g. Bispo \& Oliveira, 2007; Buckup et al. 2007) and/or taxonomic descriptions (Lima et al. 2012; Salles \& Domínguez 2012). Nonetheless, in the latest years this situation has changed, and ecological researches with mayfly have been developed (e.g. Siegloch et al. 2008, Shimano et al. 2012,2013).

In Brazil, most of the checklists of mayflies (and Leptophlebiidae) are associated to the presence of specialists on the group, such as the states of Rio de Janeiro (14 genera; 24 species; Da-Silva et al. 2010), Espírito Santo (16 genera; 22 species; Salles et al. 2010), São Paulo (13 genera; 16 species; Mariano \& Polegato, 2011), Mato Grosso (15 genera; 15 species; Shimano et al. 2011), Pernambuco (10 genera;14 species; Lima et al. 2012), and Brazilian Amazonia Region (10 genera; 19 species; Lopes et al. 2007).

Most of the knowledge on mayflies from Santa Catarina relies on the material collected by Fritz Plaumann, a German naturalist that extensively collected insects seven decades ago (Spessatto 2001). Between the decades of 1960's and 1990's several species or even genera were described based on the material collected by him (Thew 1960; Peters 1969; Domínguez \& Flowers 1989). Plaumann contributed strongly for the current knowledge of fauna and, after his studies in the State, there was not a substantial increase on descriptions of new taxa or additional records of Leptophlebiidae. With the exception of the last two new species described from Santa Catarina (Lima et al. 2013), Leptophlebiidae remains with eight genera and 16 species.

To date, the following species of Leptophlebiidae were recorded in Santa Catarina: Askola froehlichi Peters 1969, Hagenulopsis diptera Ulmer 1920, Hermanella grandis Domínguez \& Flowers 1989, Hermanella maculipennis (Ulmer 1920), Hylister plaumanni Domínguez \& Flowers 1989, Needhamella ehrhardti (Ulmer 1920), Thraulodes alapictus Mariano e Lima, 2013; T. daidaleus Thew 1960, T. limbatus Navás 1936, T. pinhoi Mariano \& Lima, 2013; T. traverae Thew 1960, T. ulmeri Edmunds 1950, Ulmeritoides haarupi (EsbenPetersen 1912), U. patagiatus (Thew 1960), U. uruguayensis (Traver 1959), and Ulmeritus balteatus Thew, 1960 (Salles et al. 2013).

Given the diversity of the group, especially in Tropical areas, and the fact that collections in Santa Catarina were performed in few and restricted areas, it is clear that the present number of taxa is underestimated. Based on that, the goals of the present report were to survey of Leptophlebiidae fauna in Western of Santa Catarina, Brazil beyond to contribute with knowledge about biology of group.

\section{Material and Methods}

\section{Region of study}

Historically, the western of Santa Catarina State has developed quickly and, thus, the dense and exuberant forest has been changed in large fragments (Testa et al. 1996; Wollf \& Schuh 2000). The economical base of region is based from little and middle farms (with lands about 10 and 15 ha) to large industrial poles, such as agribusiness. Currently, those poles still depend on farms.

The western of Santa Catarina (Figure 1) comprises an area with 27,500 sq Km that includes 118 municipalities (Programa et al. 2003) with an estimated population of 1,215 million. The climate in lower areas shows the lowest temperatures between $10^{\circ} \mathrm{C}$ and $15^{\circ} \mathrm{C}$, and highest average above $22^{\circ} \mathrm{C}$. However, higher areas show an average temperature lower than $10^{\circ} \mathrm{C}$, and the highest average up to $22{ }^{\circ} \mathrm{C}$ (Instituto 2002, Empresa... 2004).

Despite forestal formation, it is possible to divide western in three areas: Mixed Ombrophilous Forest, a forest formation with predominance of Araucaria angustifolia (Bertoloni) Otto Kuntze; high-elevation grassland with sparse presence of $A$. angustifolia, and Decidual Forest, a forest located along of Uruguai River and with marked presence of distinct decidual Lauraceae (Klein 1978; Tabarelli et al. 2005). Forest remains covering 45\% from total area of the region (SOS Mata Atlântica \& Instituto... 2009); however, only $8 \%$ belong to national or state conservation unities (Marenzi et al. 2005). The remainder forest comprises basically Legal Reserves or Permanent Preservation Areas, which are legal areas with main goal, to preserve hydrographic and geological resources, conservation of native fauna and flora.

Western of Santa Catarina is formed by tree hydrographic regions: Far-western, constituted by Peperi-Guaçú and Antas hydrographic basins, with an area about 5,900 sq Km; Middle-western region, constituted by Chapecó and Irani hydrographic basins, with an area about 11,000 sq Km and; Rio do Peixe Valley, constituted by Peixe and Jacutinga hydrographic basins, with an area of 8,2000 sq Km (Santa Catarina 1998). This hydrographic region is also considered one of those priorities areas for environmental conservation in Brazil (Brasil 2006).

In this work, 61 sites were sampled in 26 aquatic environments comprising rivers, streams, and reservoirs. From those sites, nine are situated in Far-western hydrographic region, and fifty-one, in Middle-western. The Rio do Peixe Valley hydrographic region was not sampled. Nine stations are ranked as preserved areas, forty-one as rural areas, and eleven between urban/rural areas (Table 1).

Were considered Preserved areas when sites were located inside or very close to Conservation Units, in this case, Araucária National Park and Chapecó National Forest. Were considered Rural areas when sites were strongly influenced by agricultural, livestock and, plantation of exotic trees. Finally, for the Urban/Rural areas were considered sites located in regions near or, within urban areas. Finally, sites pointed out as lenthic environments, were located closely, or inside small hydroelectric plants and hydroelectric plants as opposed of lotic environments.

\section{Material studied and identification}

Part of the specimens studied has been already deposited in collection of Laboratory of Ecology of Universidade Comunitária da Região de Chapecó. In addition, new material was collected between 


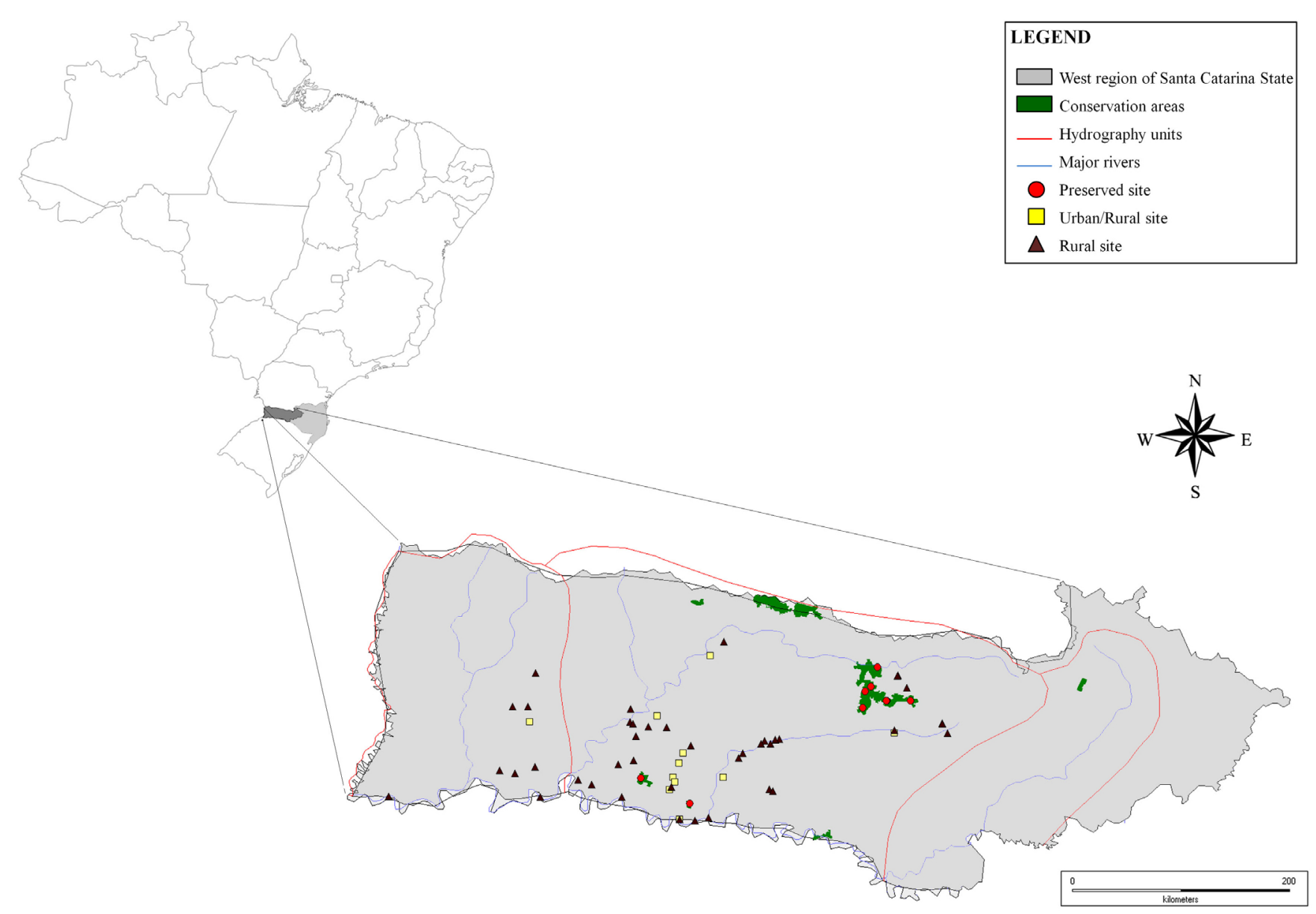

Figure 1. Map of Brazil, emphasizing the Western of Santa Catarina and sites sampled. Coordinates are on Appendix 1.

2008 and 2009 to complement the area of coverage. Samples between 2008 and 2009 were taken with Surber, frame aquatic net samplers, and also manually, sampling the most different kinds of substrata available on river (stones, leaf litter, and fine sediments).

Specimens were identified at lesser possible taxonomic level and further morphotyped. Taxonomic identification of nymphs was performed based on papers containing original descriptions and redescriptions, books and thesis (e.g. Domínguez \& Flowers 1989, Domínguez et al. 1994, 2001, 2006, Domínguez 1999, Salles et al. 2004, Salles 2006).

\section{Preparation of maps}

Data sets of coordinates were taken with GPS (Global Positioning System), and points downloaded on GPS TrackMaker ${ }^{\circledR}$ software (Ferreira Júnior 2008). A map for each genus was made using DIVA-GIS software (Hijmans et al. 2005), based in the taxa found, coordinates of sampled areas, and map of hydrographic basin in the Western Santa Catarina State.

\section{Results and Discussion}

A total of 1903 nymphs of Leptophlebiidae were identified belonging to 24 morphotypes of 12 genera (Table 2).

The richest genus of Leptophlebiidae found was Thraulodes (five morphotypes), followed by Farrodes, and Miroculis (three morphotypes). Hermanella, Homothraulus, Simothraulopsis, and Ulmeritoides were represented by two morphotypes, and Askola,
Leentvaaria, Massartela, Needhamella and Segesta by only one morphotype.

Below, a detailed description of each genera and morphotypes found in the Western Santa Catarina is presented, with the respective review about its distribution in the studied region.

Askola Peters, 1969 (Figure 2)

Of the five species of Askola recorded from Brazil, only Askola froehlichi Peters, 1969 has been reported from Santa Catarina (Salles et al. 2013). A single morphotype has been recorded in this paper.

Remarks: Askola was recorded in three rivers (Mato, Sede, and Caratuva), all of them located in regions of low order, few impacted, of high altitudes, close each other and limited at Araucaria Forest. Goulart \& Callisto (2005) and Crisci-Bispo et al. (2007) found similar results related to environment integrity where Askola is found.

Farrodes Peters, 1971 (Figure 3)

Four species of Farrodes have been recorded from Brazil, none of them to the Santa Catarina State (Salles et al. 2013). Three morphotypes have been found and, therefore, the genus is recorded for the first time from Santa Catarina.

Remarks: Morphotypes of Farrodes were broadly distributed in the region studied, and the genus did not present a clear pattern of distribution. Thereby, we could not detect a distribution pattern for Farrodes sp.2 and Farrodes sp.3, while Farrodes sp.1 occurred essentially in headwaters. As observed by Da-Silva (2002), Farrodes occurs as in water flow as in backwater, in different kind of sediments at varied altitudes. 
Raimundi, E.A. et al.

Table 1. Areas sampled in western of Santa Catarina State, followed by sites sampled, landscapes, altitudes, environments, orders of river, and comments about each site.

\begin{tabular}{|c|c|c|c|c|c|c|}
\hline $\begin{array}{l}\text { Areas sampled } \\
\text { (acronym) }\end{array}$ & Site & Landscape & $\begin{array}{l}\text { Altitude } \\
\text { (m) }\end{array}$ & $\begin{array}{c}\text { Kind of } \\
\text { Environment }\end{array}$ & $\begin{array}{l}\text { River } \\
\text { order }\end{array}$ & Comments about site \\
\hline Adami (ADM) & ADM1 & Preserved & 1155 & Lotic & Low & Mixed ombrophilous forest, in Araucárias National Park. \\
\hline \multirow[t]{2}{*}{ Caçador (CAÇ) } & CAÇ1 & Rural & 845 & Lotic & Low & $\begin{array}{l}\text { Agricultural and livestock with marginal vegetation } \\
\text { almost absent. }\end{array}$ \\
\hline & CAÇ2 & Rural & 591 & Lotic & Low & $\begin{array}{l}\text { Agricultural and livestock with marginal vegetation } \\
\text { almost absent. }\end{array}$ \\
\hline Caramuru (CAR) & CAR1 & Urban/Rural & 614 & Lotic & Low & $\begin{array}{l}\text { Open area with streets. Marginal vegetation almost } \\
\text { absent. }\end{array}$ \\
\hline Caratuva (CTV) & CTV1 & Preserved & 1065 & Lotic & Low & Mixed ombrophilous forest, in Araucárias National Park. \\
\hline \multirow[t]{5}{*}{ Chapecó (CHO) } & CHP1 & Preserved & 970 & Lotic & Higher & Mixed ombrophilous forest, in Araucárias National Park. \\
\hline & CHP2 & Rural & 285 & Lotic & Higher & Agricultural and livestock with little marginal vegetation. \\
\hline & CHP3 & Rural & 228 & Lotic & Higher & $\begin{array}{l}\text { Agricultural and livestock with marginal vegetation } \\
\text { almost absent. Mouth of river. }\end{array}$ \\
\hline & CHP4 & Rural & 600 & Lentic & Higher & $\begin{array}{l}\text { Agricultural and livestock with marginal vegetation } \\
\text { almost absent. }\end{array}$ \\
\hline & CHP5 & Urban/Rural & 529 & Lentic & Higher & $\begin{array}{l}\text { Agricultural and livestock with marginal vegetation } \\
\text { almost absent. Hydroelectric dam. }\end{array}$ \\
\hline \multirow{2}{*}{$\begin{array}{l}\text { Chapecozinho } \\
\text { (CHZ) }\end{array}$} & $\mathrm{CHZ1}$ & Rural & 1031 & Lotic & Higher & Agricultural and Eucalyptus plantation. \\
\hline & $\mathrm{CHZ2}$ & Preserved & 833 & Lotic & Higher & Mixed ombrophilous forest, in Araucárias National Park. \\
\hline \multirow[t]{3}{*}{ Iracema (IRC) } & IRC1 & Rural & 657 & Lotic & Low & $\begin{array}{l}\text { Agricultural and livestock with marginal vegetation } \\
\text { almost absent. }\end{array}$ \\
\hline & IRC2 & Rural & 430 & Lotic & Medium & $\begin{array}{l}\text { Agricultural and livestock with marginal vegetation } \\
\text { almost absent. }\end{array}$ \\
\hline & IRC3 & Rural & 229 & Lotic & Medium & $\begin{array}{l}\text { Agricultural and livestock with marginal vegetation } \\
\text { almost absent. }\end{array}$ \\
\hline \multirow[t]{12}{*}{ Irani (IRN) } & IRN1 & Rural & 1151 & Lotic & Higher & $\begin{array}{l}\text { Agricultural and livestock with much marginal } \\
\text { vegetation. Near of Araucárias National Park. }\end{array}$ \\
\hline & IRN2 & Urban/Rural & 1046 & Lotic & Higher & $\begin{array}{l}\text { Agricultural and camping area with marginal vegetation } \\
\text { almost absent. }\end{array}$ \\
\hline & IRN3 & Rural & 594 & Lotic & Medium & Agricultural and livestock with little marginal vegetation. \\
\hline & IRN4 & Rural & 533 & Lotic & Higher & $\begin{array}{l}\text { Agricultural and livestock with marginal vegetation } \\
\text { almost absent }\end{array}$ \\
\hline & IRN5 & Rural & 470 & Lotic & Medium & Agricultural and Eucalyptus plantation. \\
\hline & IRN6 & Rural & 872 & Lotic & Medium & Agricultural and livestock with little marginal vegetation. \\
\hline & IRN7 & Rural & 514 & Lotic & Higher & $\begin{array}{l}\text { Agricultural and livestock with marginal vegetation } \\
\text { absent. }\end{array}$ \\
\hline & IRN8 & Rural & 505 & Lotic & Higher & Agricultural and livestock with little marginal vegetation. \\
\hline & IRN9 & Rural & 466 & Lentic & Higher & Agricultural and livestock with little marginal vegetation. \\
\hline & IRN10 & Rural & 667 & Lotic & Higher & Agricultural and livestock with little marginal vegetation. \\
\hline & IRN11 & Urban/Rural & 329 & Lotic & Higher & Agricultural and livestock with little marginal vegetation. \\
\hline & IRN12 & Rural & 291 & Lentic & Higher & $\begin{array}{l}\text { Agricultural and livestock with marginal vegetation } \\
\text { almost absent. Mouth of river. }\end{array}$ \\
\hline \multirow{2}{*}{$\begin{array}{l}\text { Lajeado Bonito } \\
\text { (LBO) }\end{array}$} & LBO1 & Rural & 526 & Lotic & Low & Livestock with marginal vegetation almost absent. \\
\hline & LBO2 & Rural & 312 & Lentic & Low & Agricultural and livestock with little marginal vegetation. \\
\hline $\begin{array}{l}\text { Lajeado Divisa } \\
\text { (LDV) }\end{array}$ & LDV1 & Preserved & 662 & Lotic & Low & Estacional decidual forest, in Chapecó National Forest. \\
\hline \multirow[t]{5}{*}{$\begin{array}{l}\text { Lajeado São José } \\
\text { (LSJ) }\end{array}$} & LJS1 & Urban/Rural & 647 & Lotic & Medium & $\begin{array}{l}\text { Agricultural and Eucalyptus plantation with marginal } \\
\text { vegetation almost absent. }\end{array}$ \\
\hline & LJS2 & Urban/Rural & 635 & Lotic & Medium & $\begin{array}{l}\text { Agricultural with little marginal vegetation. Near factory } \\
\text { of fiber pools. }\end{array}$ \\
\hline & LJS3 & Urban/Rural & 606 & Lentic & Medium & Agricultural and livestock with little marginal vegetation. \\
\hline & LJS4 & Urban/Rural & 498 & Lotic & Medium & $\begin{array}{l}\text { Estacional decidual forest. River has already passed } \\
\text { through all urban area of Chapecó city. }\end{array}$ \\
\hline & LJS5 & Rural & 498 & Lotic & Medium & Livestock and estacional decidual forest. \\
\hline
\end{tabular}


Table 1. Continued...

\begin{tabular}{|c|c|c|c|c|c|c|}
\hline $\begin{array}{l}\text { Areas sampled } \\
\text { (acronym) }\end{array}$ & Site & Landscape & $\begin{array}{l}\text { Altitude } \\
(\mathrm{m})\end{array}$ & $\begin{array}{c}\text { Kind of } \\
\text { Environment }\end{array}$ & $\begin{array}{l}\text { River } \\
\text { order }\end{array}$ & Comments about site \\
\hline \multirow[t]{2}{*}{ Lambedor (LAM) } & LAM1 & Rural & 638 & Lotic & Low & $\begin{array}{l}\text { Agricultural and livestock with marginal vegetation } \\
\text { almost absent. }\end{array}$ \\
\hline & LAM2 & Rural & 346 & Lotic & Low & Livestock and estacional decidual forest. \\
\hline $\begin{array}{l}\text { Marconstrói } \\
(\mathrm{MCT})\end{array}$ & MAR1 & Preserved & 950 & Lotic & Low & Mixed ombrophilous forest, in Araucárias National Park. \\
\hline \multirow[t]{2}{*}{ Mato (MAT) } & MTO1 & Preserved & 873 & Lotic & Low & Mixed ombrophilous forest, in Araucárias National Park. \\
\hline & MTO2 & Preserved & 873 & Lotic & Low & Mixed ombrophilous forest, in Araucárias National Park. \\
\hline $\begin{array}{l}\text { Monte Alegre } \\
\text { (MAL) }\end{array}$ & MAL1 & Rural & 302 & Lotic & Low & $\begin{array}{l}\text { Agricultural and livestock with marginal vegetation } \\
\text { almost absent. Mouth of river. }\end{array}$ \\
\hline \multirow[t]{2}{*}{ Palmitos (PAL) } & PAL1 & Rural & 429 & Lotic & Low & $\begin{array}{l}\text { Agricultural and livestock with marginal vegetation } \\
\text { almost absent. }\end{array}$ \\
\hline & PAL2 & Rural & 363 & Lotic & Low & $\begin{array}{l}\text { Agricultural and livestock with marginal vegetation } \\
\text { almost absent. Mouth of river. }\end{array}$ \\
\hline \multirow[t]{2}{*}{ Pitoco (PIT) } & PIT1 & Urban/Rural & 278 & Lotic & Low & $\begin{array}{l}\text { Estacional decidual forest with area destined to rural } \\
\text { tourism. }\end{array}$ \\
\hline & PIT2 & Urban/Rural & 289 & Lotic & Low & $\begin{array}{l}\text { Estacional decidual forest with area destined to rural } \\
\text { tourism. }\end{array}$ \\
\hline Santa Fé (STF) & STF1 & Rural & 293 & Lotic & Low & Livestock with marginal vegetation almost absent. \\
\hline $\begin{array}{l}\text { Santo Antônio dos } \\
\text { Pinhais (SAP) }\end{array}$ & SAP1 & Rural & 368 & Lotic & Low & $\begin{array}{l}\text { Agricultural and livestock with marginal vegetation } \\
\text { almost absent. }\end{array}$ \\
\hline \multirow[t]{3}{*}{$\begin{array}{l}\text { São Domingos } \\
\text { (SDM) }\end{array}$} & SDM1 & Rural & 605 & Lotic & Medium & $\begin{array}{l}\text { Agricultural and livestock with marginal vegetation } \\
\text { almost absent. }\end{array}$ \\
\hline & SDM2 & Urban/Rural & 516 & Lotic & Medium & $\begin{array}{l}\text { Agricultural and livestock with marginal vegetation } \\
\text { absent. Near the city. }\end{array}$ \\
\hline & SDM3 & Rural & 292 & Lotic & Medium & $\begin{array}{l}\text { Agricultural and livestock with marginal vegetation } \\
\text { almost absent. }\end{array}$ \\
\hline \multirow[t]{2}{*}{ Sede (SED) } & SED1 & Rural & 1046 & Lotic & Low & $\begin{array}{l}\text { Agricultural and Eucalyptus plantation. Near Araucárias } \\
\text { National Park. }\end{array}$ \\
\hline & SED2 & Rural & 1044 & Lotic & Low & $\begin{array}{l}\text { Agricultural and Eucalyptus plantation. Near Araucárias } \\
\text { National Park. }\end{array}$ \\
\hline \multirow[t]{2}{*}{ Taquaruçú (TAQ) } & TAQ1 & Rural & 617 & Lotic & Low & Livestock with marginal vegetation almost absent. \\
\hline & TAQ2 & Rural & 436 & Lotic & Low & $\begin{array}{l}\text { Agricultural and livestock with marginal vegetation } \\
\text { absent. }\end{array}$ \\
\hline \multirow[t]{3}{*}{ Tarumã (TAR) } & TAR1 & Rural & 503 & Lotic & Low & $\begin{array}{l}\text { Agricultural and livestock with marginal vegetation } \\
\text { absent. }\end{array}$ \\
\hline & TAR2 & Rural & 414 & Lotic & Low & Agricultural and livestock with little marginal vegetation. \\
\hline & TAR3 & Rural & 303 & Lotic & Low & $\begin{array}{l}\text { Agricultural and livestock with marginal vegetation } \\
\text { absent. }\end{array}$ \\
\hline Tigre (TIG) & TGR1 & Preserved & 572 & Lotic & Low & Estacional decidual forest, in Chapecó National Forest. \\
\hline Vargem Bonita & VAR1 & Rural & 1161 & Lotic & Low & Eucalyptus plantation and estacional decidual forest. \\
\hline (VAB) & VAR2 & Rural & 1159 & Lotic & Low & Eucalyptus plantation and estacional decidual forest. \\
\hline Xaxim (XAX) & XAX1 & Urban/Rural & 729 & Lotic & Low & $\begin{array}{l}\text { Agricultural and livestock with marginal vegetation } \\
\text { almost absent. }\end{array}$ \\
\hline
\end{tabular}

Hermanella NEEDHAM \& MURPHY, 1924 (Figure 4)

Of the four species recorded from Brazil, only Hermanella grandis Domínguez \& Flowers, 1989 and Hermanella maculipennis (Ulmer 1920) have been reported from Santa Catarina (Salles et al. 2013). Two morphotypes have been recorded in this paper.

Remarks: Most of the nymphs of Hermanella were recorded in Conservation Unities, such as Chapecó National Forest (Lajeado Divisa River) and Araucária Nationak Park (Caratuva, and Chapecozinho), or in regions very conserved, such as Irani,
Marconstrói, and Sede rivers. Nymphs of the genus were most representative in regions of high altitude. However, Hermanella sp.2 was also found in the Lajeado Divisa River, situated in lower altitudes. Hermanella cf. grandis occurred in just one point at higher altitudes of the Irani River.

Homothraulus DEMOULIN, 1955 (Figure 5)

Only one species of Homothraulus is recorded from Brazil. Homothraulus misionensis (Esben-Petersen, 1912) has been previously recorded from South Brazil but specific locations were 
Table 2. Distribution list of Leptophlebiidae in western of Santa Catarina, followed by areas sampled*, frequency of records and abundance.

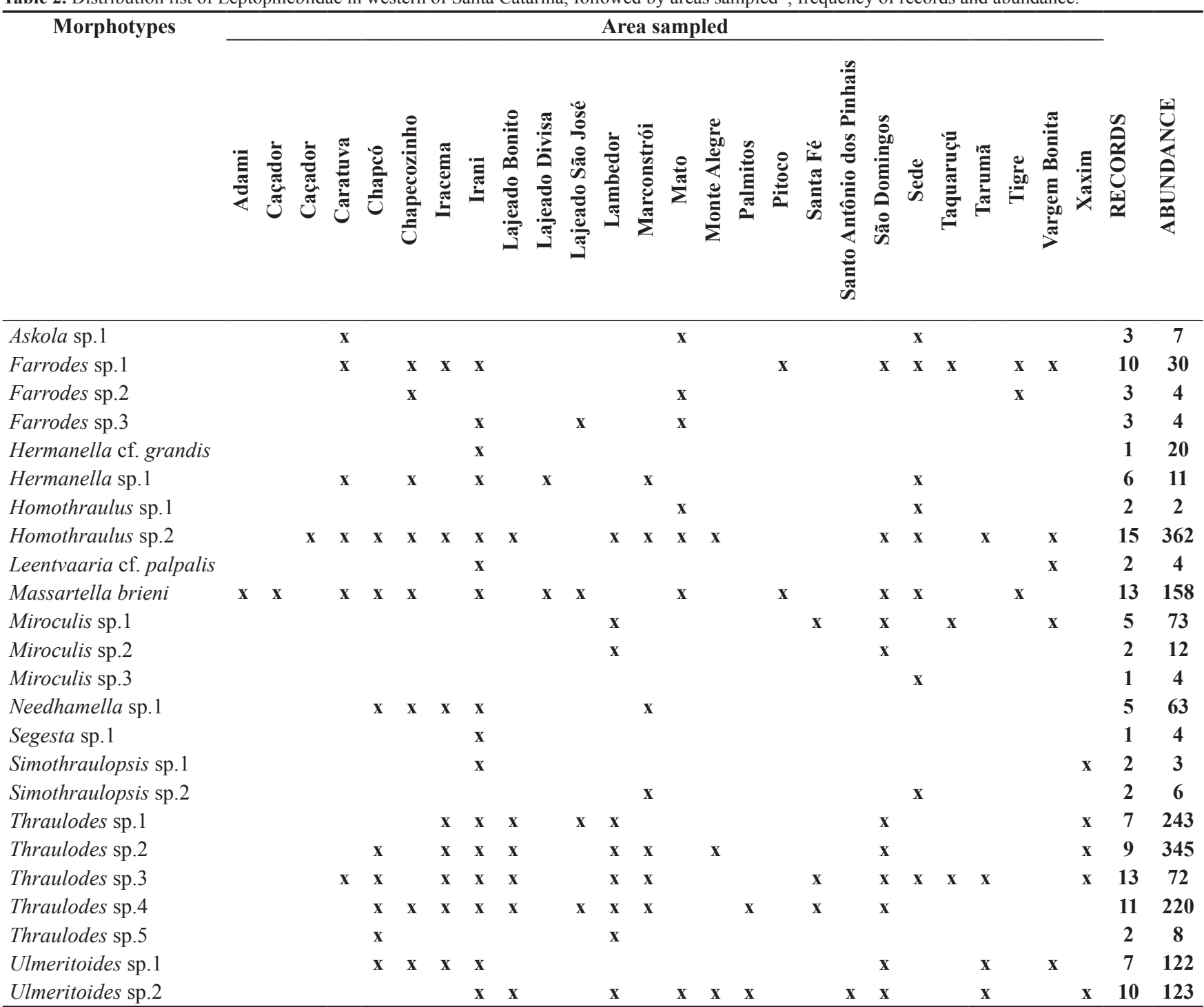

*In this case, sites sampled (e.g. CAÇ1; CAÇ2) were considered as only one area (CAÇ).

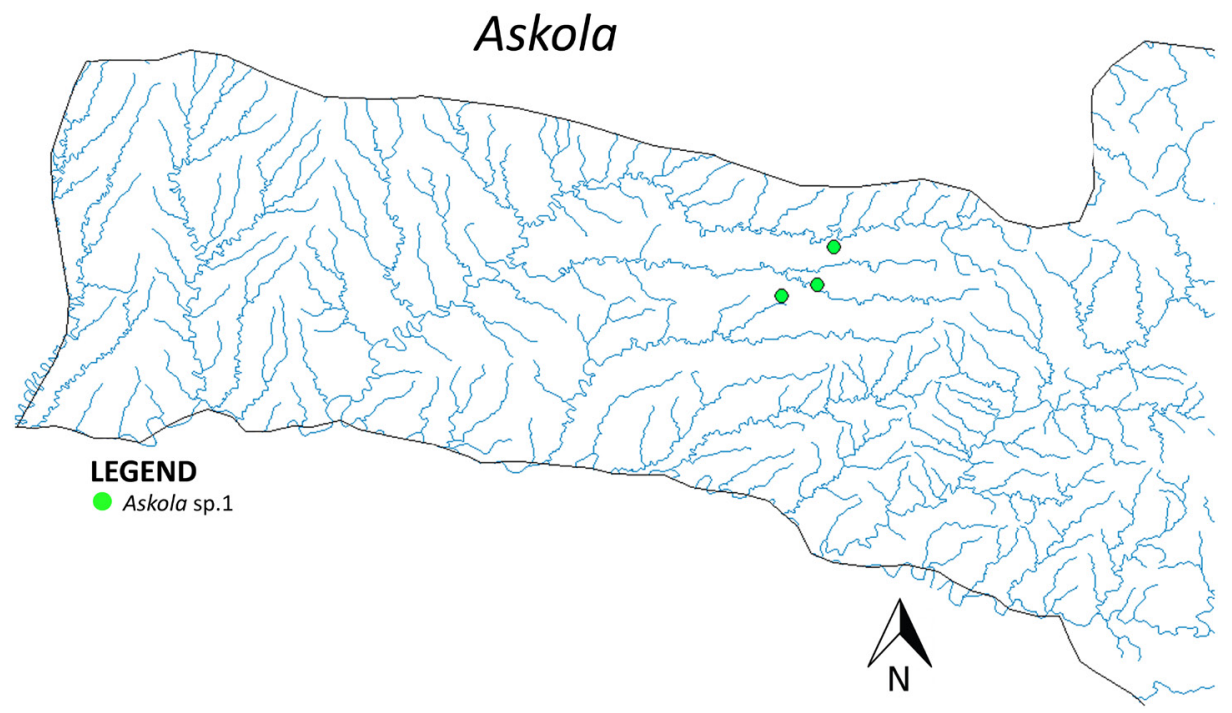

Figure 2. Geographic distribution of Askola Peters, 1969 in the Western Santa Catarina. 


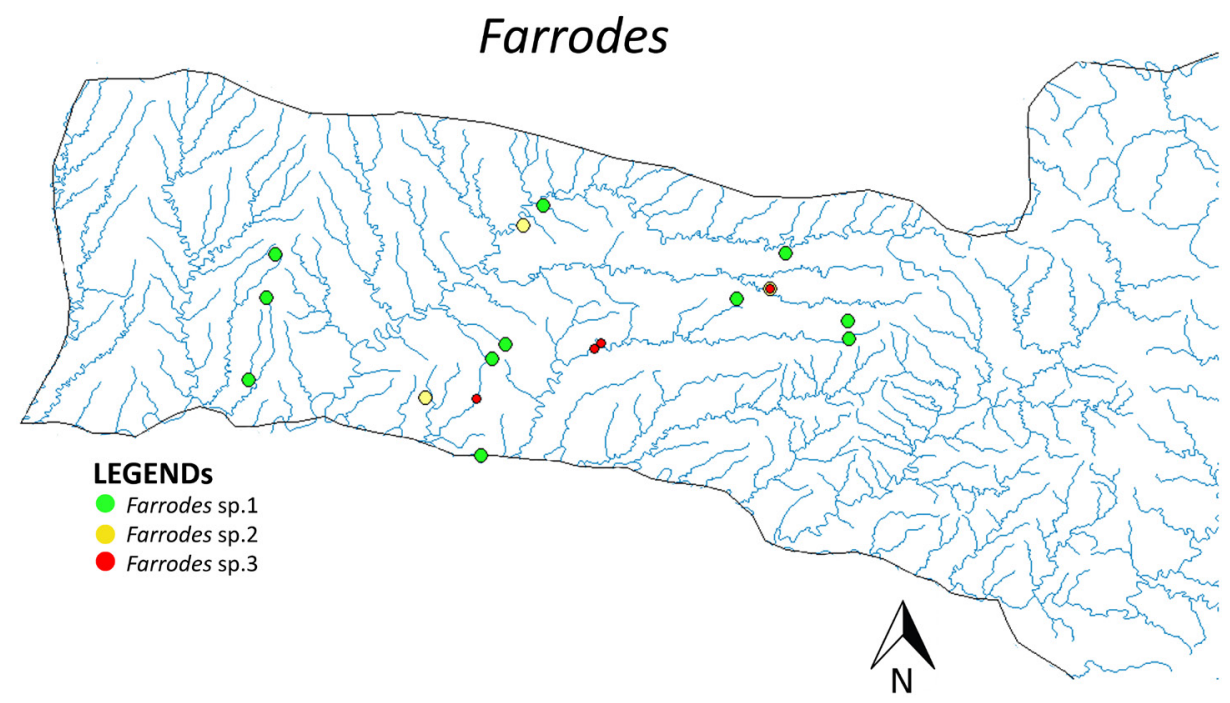

Figure 3. Geographic distribution of Farrodes Peters, 1971 in the Western Santa Catarina.

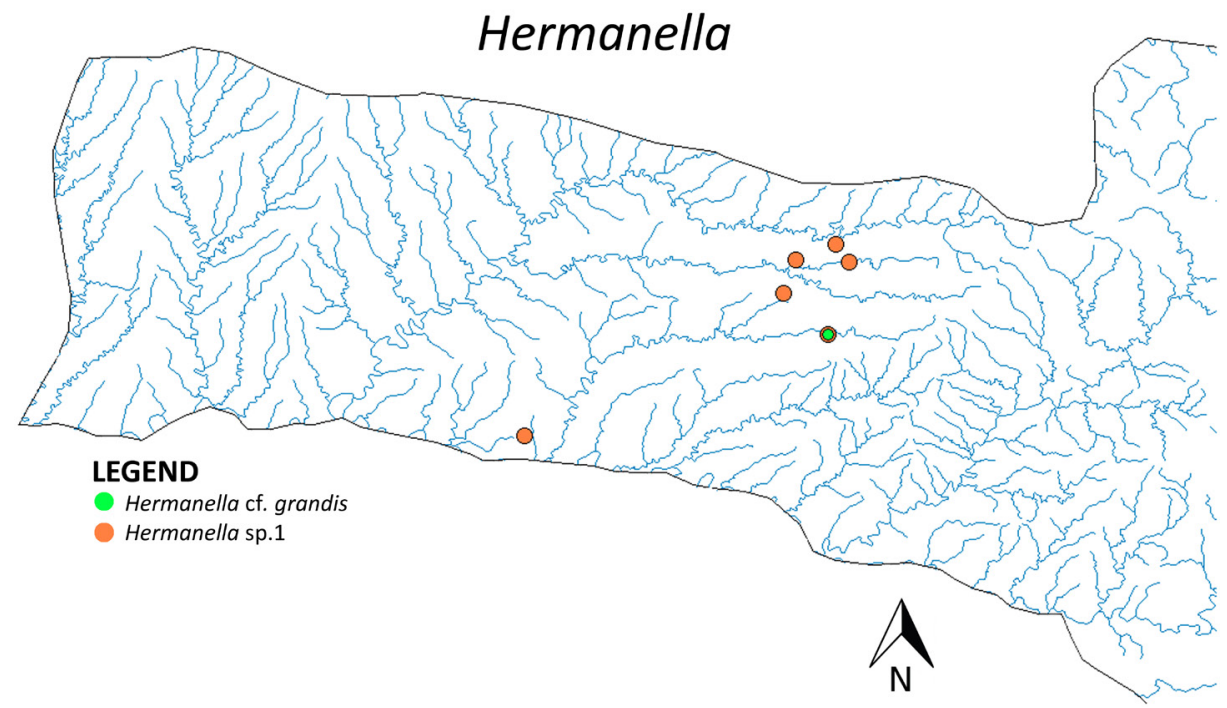

Figure 4. Geographic distribution of Hermanella Needham \& Murphy, 1924 in the Western Santa Catarina.

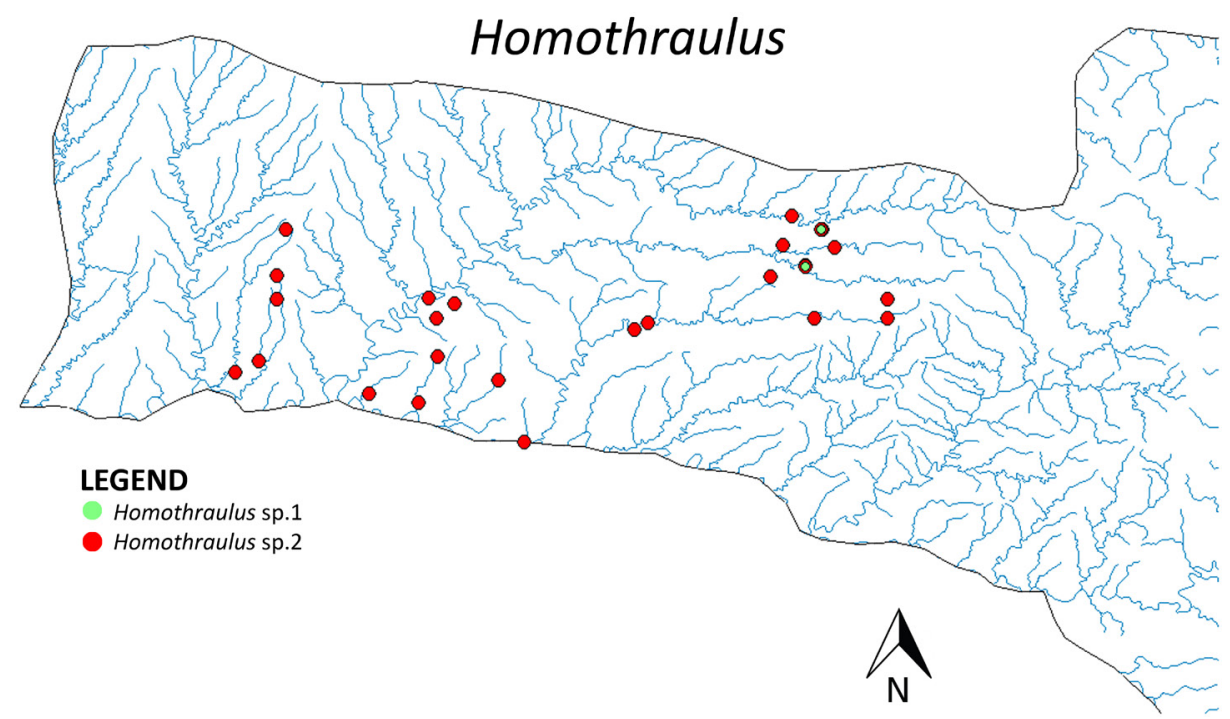

Figure 5. Geographic distribution of Homothraulus Demoulin, 1955 in the Western Santa Catarina. 
not pointed out. (Domínguez et al. 1997). Two morphotypes have been recorded in this paper.

Remarks: Homothraulus was widely distributed, occupying all different kinds of sites, with a range of altitude varying from $252 \mathrm{~m}$ to $1151 \mathrm{~m}$.

Homothraulus sp.2 was widely distributed, while Homothraulus sp.1 was recorded only in two first order rivers (Mato, and Sede), both with moderated flow of water, sediment with pebble and leaf litter, and restricted to area covered by dense vegetation of Araucaria Forest. According to Domínguez et al. (2006), nymphs of Homothraulus are found in streams and rivers, but with rapid water flow.

Leentvaaria DEMOULIN, 1966 (Figure 6)

One species of Leentvaaria has been recorded from Brazil, but not from Santa Catarina (Salles et al. 2013). In this paper one morphotype has been found and, therefore, the genus is recorded for the first time from Santa Catarina.

Remarks: Leentvaaria was limited to the Irani and Vargem Bonita rivers. Vargem Bonita is a river that belongs to the watershed of the Irani River. Nymphs occurred in environments characterized by strong water flow and under stones. Small hydro power plants, therefore, can compromise the establishment of Leentvaaria cf. palpallis in the Irani River, since that kind of construction convert rhithral in pothamal environments.

Massartella LESTAGE, 1930 (Figure 7)

Two species of Massartella have been recorded in Brazil, none of them to the Santa Catarina State (Salles et al. 2013). In this paper one morphotypes has been found and, therefore, the genus is recorded for the first time from Santa Catarina.

Remarks: Massartella brieni (Lestage, 1924) was also a species widely distributed. It appeared in 13 sites, with different kinds of land used. According to Pescador \& Peters (1990), the range of altitude for Massartella varies from 500 to $1600 \mathrm{~m}$. In this study, M. brieni was recorded in altitudes lower than $250 \mathrm{~m}$ (Pitoco River).

Miroculis EDMUNDS, 1963 (Figure 8)

Ten species of Miroculis have been recorded in Brazil, none of them to the Santa Catarina State (Salles et al. 2013). In this paper three morphotypes have been found and, therefore, the genus is recorded for the first time from Santa Catarina.

Remarks: Morphotypes of Miroculis were associated to tributaries of the largest rivers sampled: Chapecó, Irani, and Uruguai. Miroculis sp.1, although found in few points, was widely distributed, occurring mainly in headwaters. Contrastingly, Miroculis sp. 2 occurred in altitudes lower than $650 \mathrm{~m}$, with impacted environments, while Miroculis sp. 3 was restricted to altitudes higher than $1000 \mathrm{~m}$, at environments with little anthropic influence and in the Araucaria Forest.

\section{Needhamella Domínguez \& Flowers, 1989 (Figure 9)}

Of the two species of Needhamella recorded in Brazil, only Needhamella ehrhardti (Ulmer, 1920) has been reported from Santa Catarina (Salles et al. 2013). A single morphotype has been recorded in this paper.

Remarks: Needhamella sp.1 was recorded in two sites with distinct situations: the first one was located at higher altitudes (highest altitude is in the Chapecozinho River - 1031m) and in regions less impacted. The other one was located at lowest altitudes (Iracema River - 252m), and in areas that present significant impact. Although Needhamella has been widely distributed in the region, the genus is associated to open environments, rivers of lower order, and moderate and strong water flow. The same pattern was pointed out by Domínguez \& Flowers (1989).

Segesta Siegloch \& Polegatto, 2006 (Figure 10)
One species of Segesta has been recorded in Brazil, but not to the Santa Catarina State (Salles et al. 2013). In this paper one morphotype has been found, therefore, the genus is recorded for the first time from Santa Catarina.

Remarks: Segesta sp.1 was recorded in one sample site, in the mouth of the Irani River. Segesta riograndensis Siegloch et al. (2006) has been recorded in the states of Rio Grande do Sul (its type locality), and Mato Grosso do Sul (Righi-Cavallaro et al. 2008). In this study, Segesta sp.1 was found in rocky environment, water with strong flow, and at lower altitudes. Interestingly, the same observation was previously pointed out by Siegloch et al. (2006) for the genus and the species.

Simothraulopsis DEMOULIN, 1966 (Figure 11)

Five species of Simothraulopsis have been previously recorded from Brazil, none of them to the Santa Catarina State (Salles et al. 2013). In this paper two morphotypes have been found and, therefore, the genus is recorded for the first time from Santa Catarina.

Remarks: Simothraulopsis sp.1 occurred in a low order portion of one large river, and in one stream (Irani and Xaxim rivers, respectively). Simothraulopsis $\mathrm{sp} .2$ was restricted to higher altitudes and better conserved region. All nymphs occurred in altitudes above $700 \mathrm{~m}$.

Thraulodes Ulmer, 1920 (Figure 12)

Of the thirteen species of Thraulodes recorded from Brazil, only Thraulodes alapictus Mariano \& Lima, 2013; Thraulodes daidaleus Thew, 1960; Thraulodes limbatus Navás, 1936; Thraulodes pinhoi Mariano \& Lima, 2013; Thraulodes traverae Thew, 1960; Thraulodes ulmeri Edmunds, 1950 have been reported from Santa Catarina (Salles et al. 2013). Five morphotypes have been recorded in this paper.

Remarks: Thraulodes was the genus that showed higher number of morphotypes and higher number of occurrences, especially Thraulodes sp.1, Thraulodes sp.2, Thraulodes sp.3, and Thraulodes sp.4. On the other hand, Thraulodes sp.5 was recorded in two points that presented distinct environmental characteristics: the first one is the Caramurú River, a small river located in urban area at lower altitudes (600m or less). The other region is Irani River, which is a large-size river and is located at higher altitudes $(1000 \mathrm{~m})$.

Thraulodes was recorded in points with both presence and absence of anthropic influence. The type locality of Thraulodes quevedoensis Flowers 2009 that has been described from Ecuador, for example, is a River that receives human waste and chemical residue coming from agriculture (Flowers 2009).

Ulmeritoides TRAVER, 1959 (Figure 13)

Of the ten species of Ulmeritoides recorded in Brazil, only Ulmeritoides haarupi (Esben-Petersen, 1912); Ulmeritoides patagiatus (Thew, 1960); Ulmeritoides uruguayensis (Traver, 1959); Ulmeritus balteatus Thew, 1960 have been reported from Santa Catarina (Salles et al. 2013). Two morphotypes have been recorded in this paper.

Remarks: Ulmeritoides did not show a clear distribution pattern, occurring in points with varied altitudes, in different kinds of lands used, and at different orders.

\section{Discussion}

In the present study, the number of genera recorded in Santa Catarina increased from eight to 15 . Although have been recorded a high number of morphotypes (24), most part could not be identified at the specie level, once the adult stage is imperative for an accurate identification of most of the species. Besides the fact that several species, or even genera, were described based solely on adult stages, 


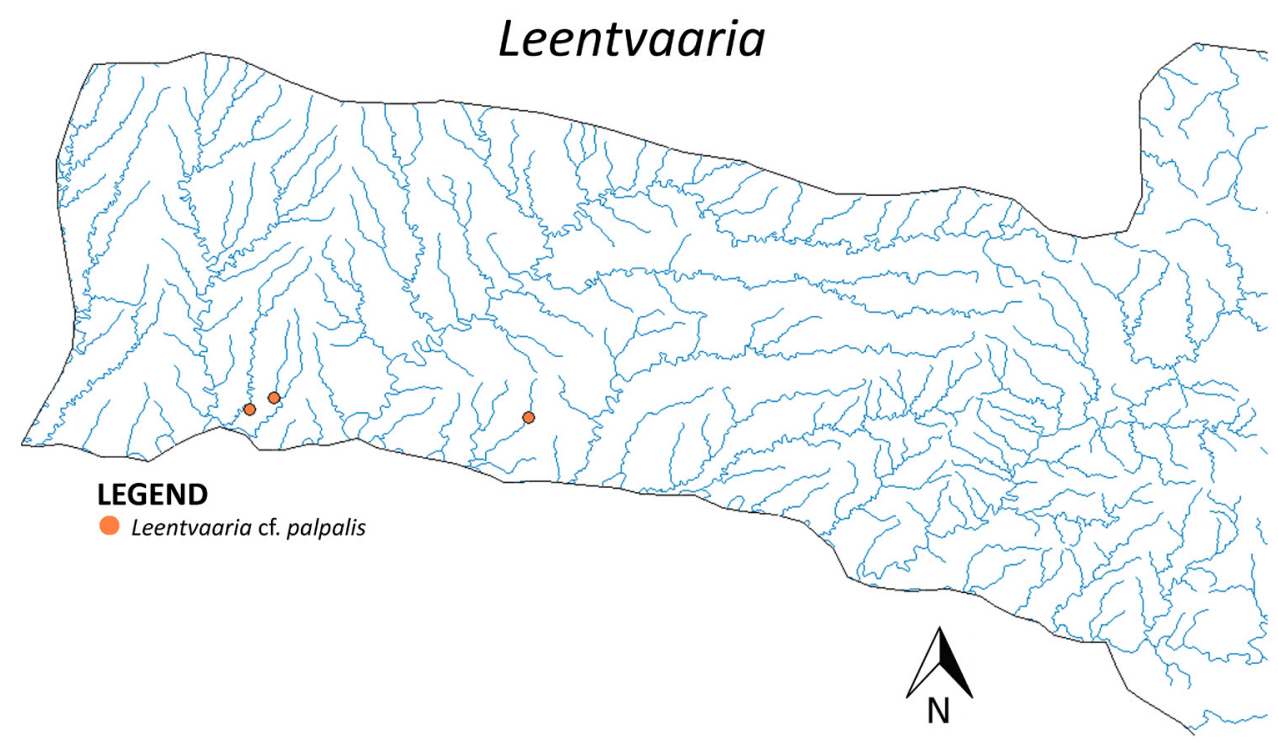

Figure 6. Geographic distribution of Leentvaaria Demoulin, 1966 in the Western Santa Catarina.

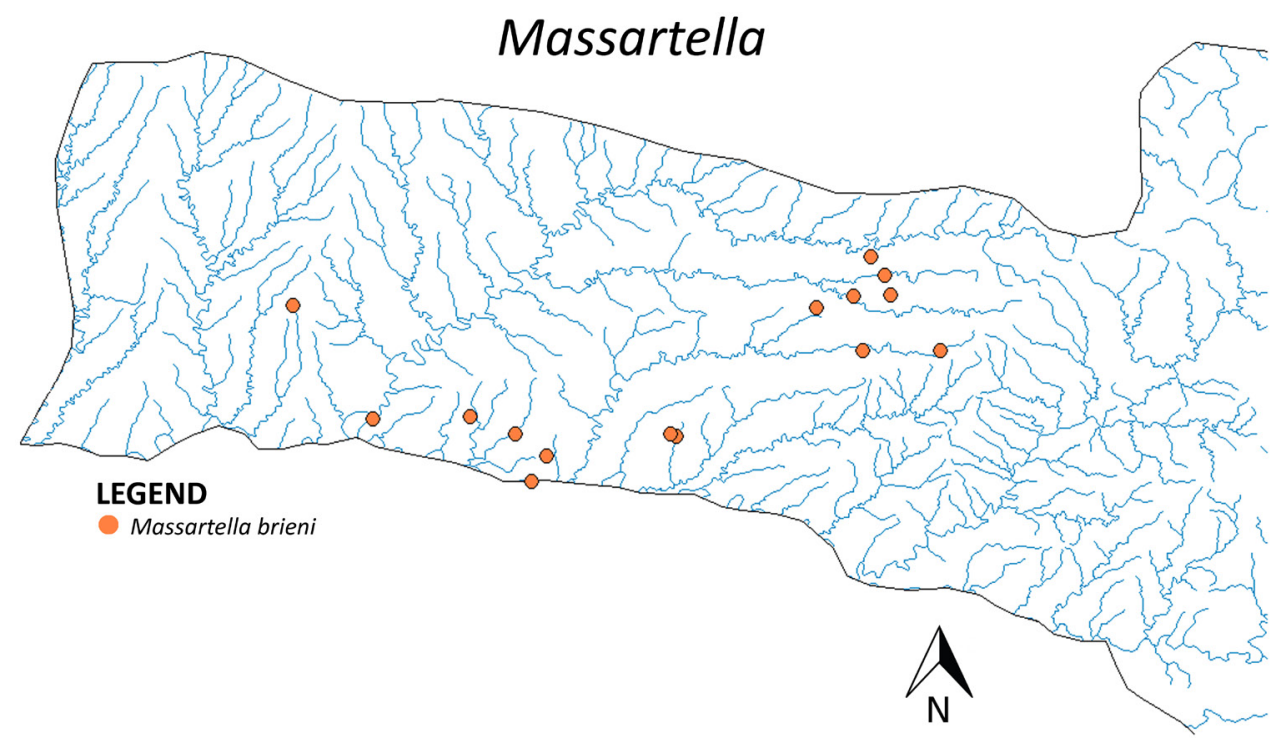

Figure 7. Geographic distribution of Massartella Lestage, 1930 in the Western Santa Catarina.

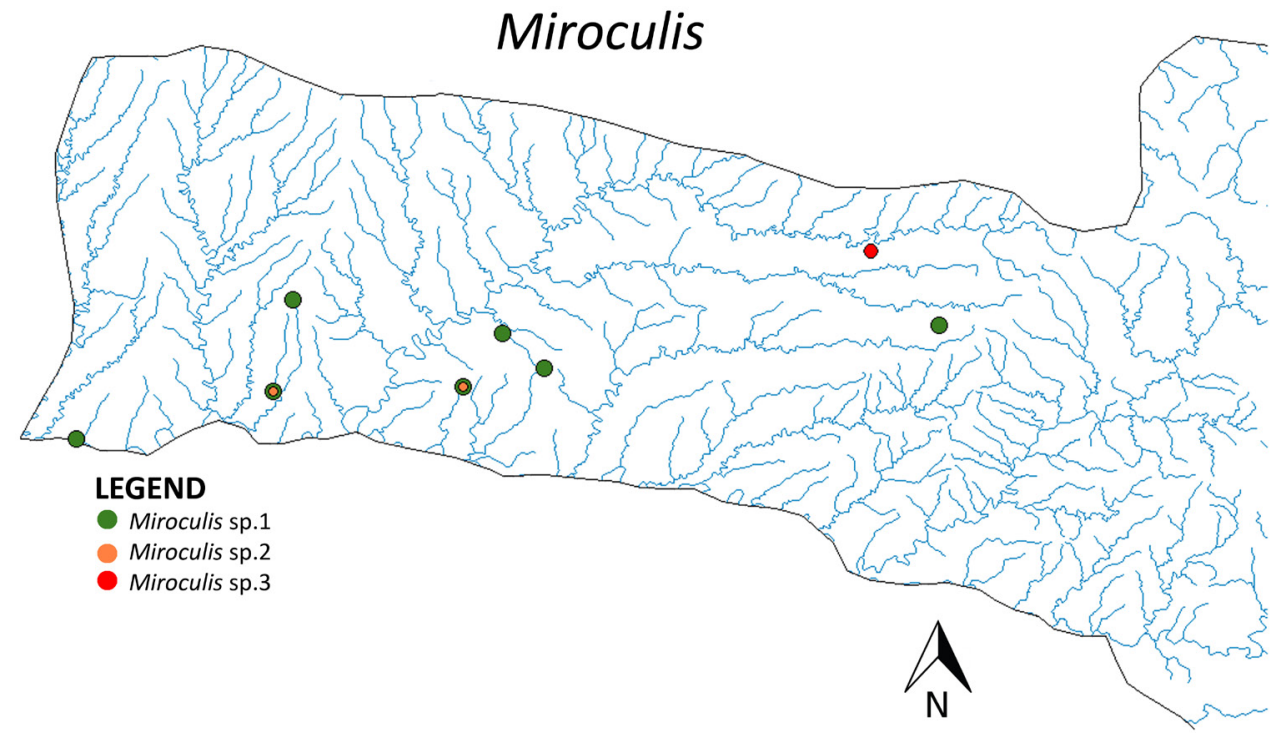

Figure 8. Geographic distribution of Miroculis Edmunds, 1963 in the Western Santa Catarina. 


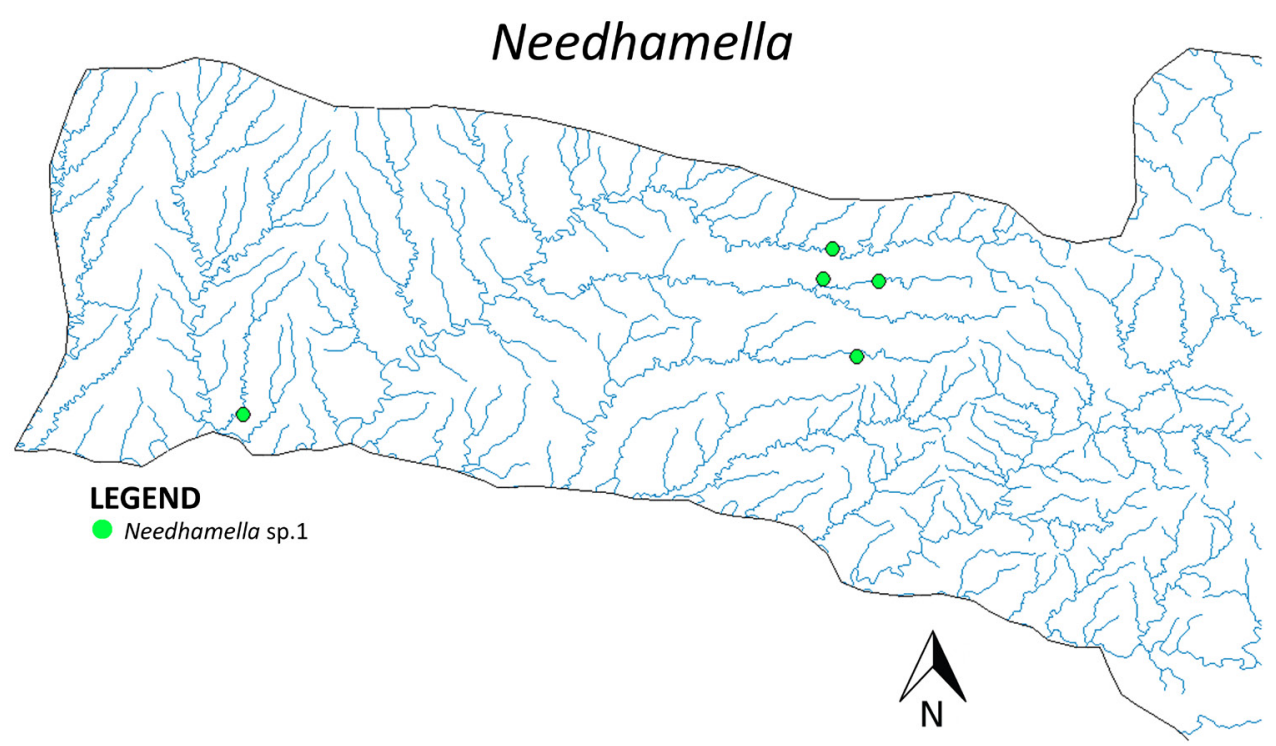

Figure 9. Geographic distribution of Needhamella Domínguez \& Flowers, 1989 in the Western Santa Catarina.

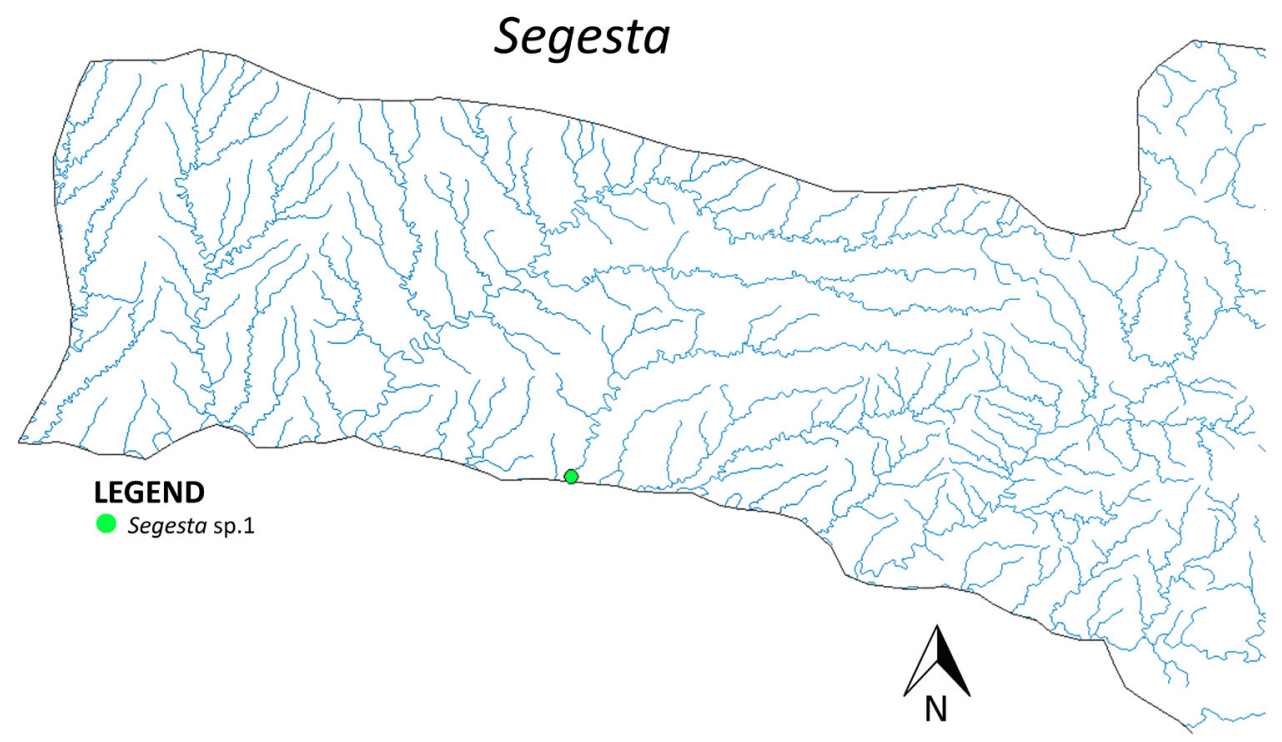

Figure 10. Geographic distribution of Segesta Siegloch \& Polegatto, 2006 in the Western Santa Catarina.

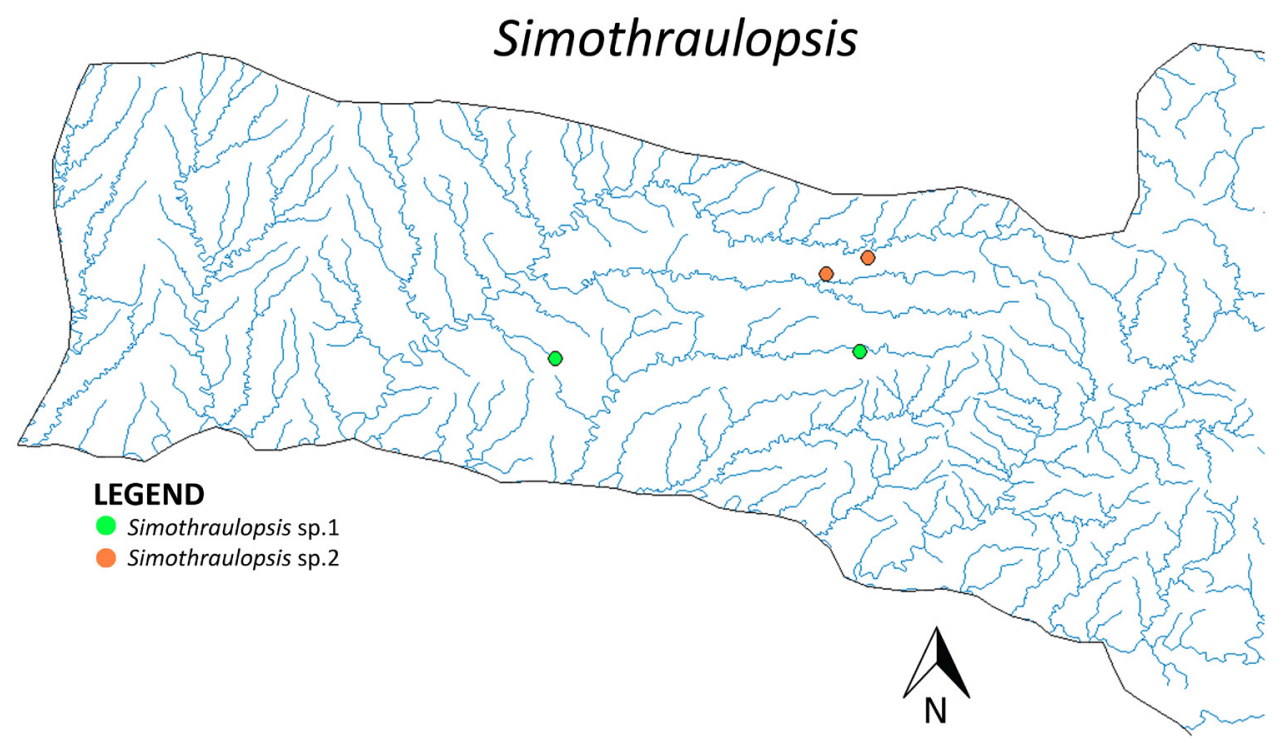

Figure 11. Geographic distribution of Simothraulopsis Demoulin, 1966 in the Western Santa Catarina. 


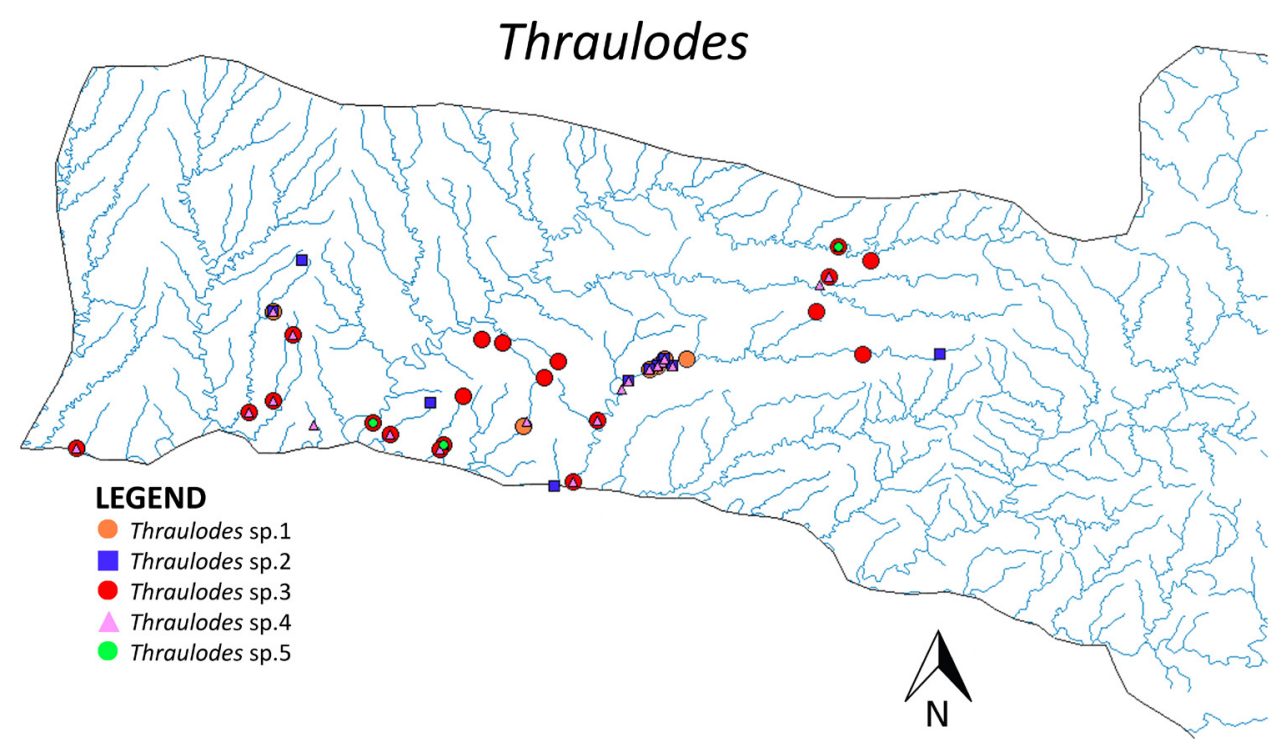

Figure 12. Geographic distribution of Thraulodes Ulmer, 1920 in the Western Santa Catarina.

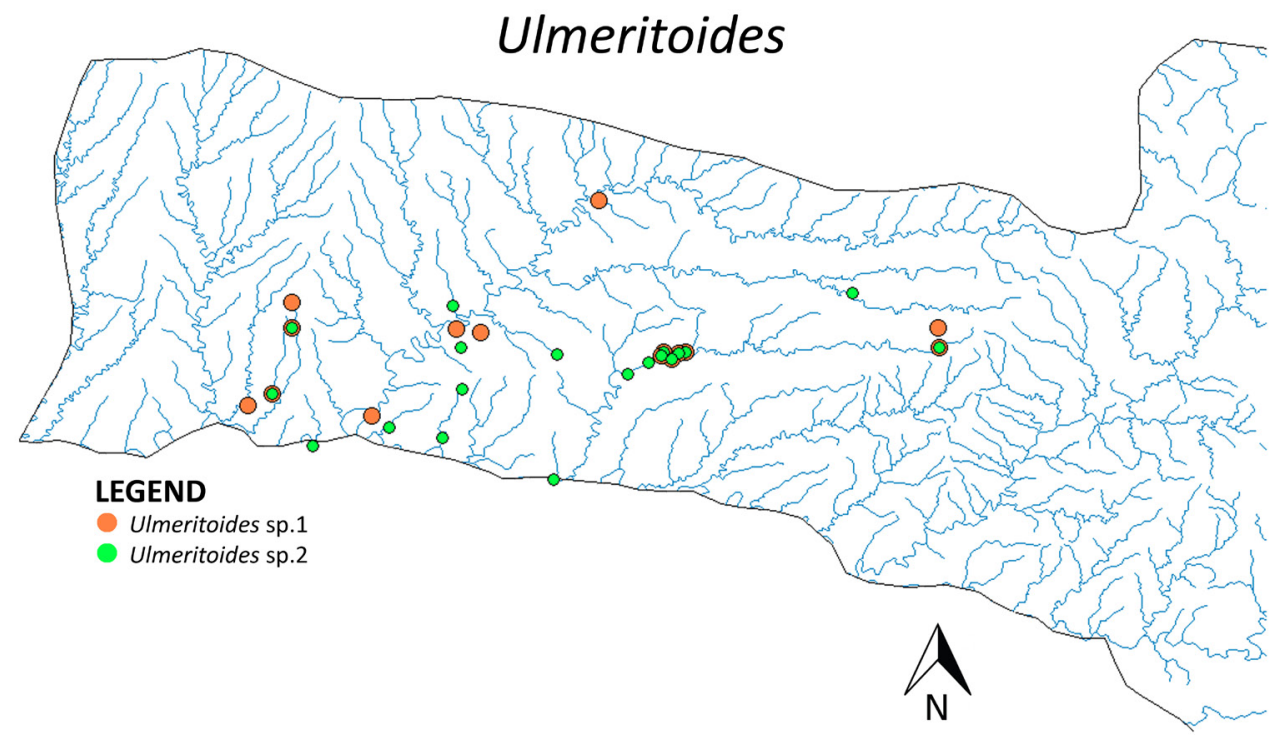

Figure 13. Geographic distribution of Ulmeritoides Traver, 1959 in the Western Santa Catarina.

the number of species not described, especially in tropical areas, is extremely high.

Four genera were limited at specific areas; Leentvaaria and Hermanella were associated with regions more conserved, and Needhamella and Segesta were found exclusively in the Irani River. These environments are suffering strong anthropic influence, either by the constructions of small hydro power plant, or by planting of Pinus and Eucalyptus along the banks of the Chapecó and Chapecozinho rivers. That king of impact can interfere directly the environment.

In conclusion, this study allowed us to advance the knowledge regarding the composition of Leptophlebiidae nymphs from Western region of Santa Catarina State, and to improve some information on biology of group. To supplement this information is necessary to know the imago stage (specially associating nymph and imago) in order to accurate identification at species level to all genera of family. Thus, it will be possible to provide a better knowledge about taxonomy and then, natural history of group.

\section{Acknowledgements}

We are thankful to João Carlos Marocco, Bruna Turra, Simone Piltz and Antônio Ganzer for their help on fieldwork and laboratory. To Dr. Denis Rosemberg and anonymous reviewers for their valuable comments on the manuscript. To Ambiental Equilibrio for providing nymphs of Leptophlebiidae, and to Unochapecó and Associação de Preservação do Meio Ambiente e da Vida - APREMAVI, important for logistic support. We are also grateful to CAPES, and FAPESC for scholarship provided for the first author, and to CNPq for productivity scholarship provided for the second author.

\section{References}

BARBER-JAMES, H., GATTOLLIAT, J.L., SARTORI M. \& HUBBARD, M.D. 2008. Global diversity of mayflies (Ephemeroptera, Insecta) in freshwater. Hydrobiologia. 595:339-350. http://dx.doi.org/10.1007/ s10750-007-9028-y 
BISPO, P.C. \& OLIVEIRA, L.G. 2007. Diversity and structure of Ephemeroptera, Plecoptera and Trichoptera (Insecta) assemblages from riffles in mountain streams of Central Brazil. Rev. Bras. Zool. 24(2):283293. http://www.scielo.br/pdf/rbzool/v24n2/a04v24n2.pdf (last access at 10/25/2009).

BRASIL. Ministério do Meio Ambiente. Plano Nacional de Recursos Hídricos - MMA. 2006. Panorama e estado dos recursos hídricos do Brasil. Secretaria de Recursos Hídricos Brasília, Brasília.

BUCKUP, L., BUENO, A.A.P., BOND-BUCKUP, G., CASAGRANDE, M. \& MAJOLO, F. 2007. The benthic macroinvertebrate fauna of highland streams in southern Brazil: composition, diversity and structure. Rev. Bras. Zool. 24(2): 294-301. http://www.scielo.br/pdf/rbzool/v24n2/a05v 24n2.pdf (last access at 06/15/2009).

CRISCI-BISPO, V.L., BISPO, P.C. \& FROEHLICH, C.G. 2007. Ephemeroptera, Plecoptera and Trichoptera assemblages in litter in a mountain stream of the Atlantic Rainforest from Southeastern Brazil. Rev. Bras. Zool. 24(3):545-551. http://dx.doi.org/10.1007/s10750-007-9028-y

DA-SILVA, E.R. 2002. Descrição da ninfa de Farrodes carioca Domínguez, Molineri \& Peters, 1996 (Insecta, Ephemeroptera, Leptophlebiidae). Bol. Mus. Nac. Zool. 495:1-5.

DA-SILVA, E.R., NESSIMIAN, J.L. \& COELHO, L.B.N. 2010. Leptophlebiidae ocorrentes no Estado do Rio de Janeiro, Brasil: hábitats, meso-hábitats e hábitos das ninfas (Insecta: Ephemeroptera). http://www. biotaneotropica.org.br/v10n4/pt/fullpaper?bn01410042010+pt (last access at 08/21/2012).

DOMÍNGUEZ, E. \& FLOWERS, W. 1989. A Revision of Hermanella and related genera (Ephemeroptera: Leptophlebiidae; Atalophlebiinae) from Subtropical South America. Ann. Entomol. Soc. Am. 82(5):555-573.

DOMÍNGUEZ, E. 1999. Systematics, cladistics and biogeography of the American genus Farrodes (Ephemeroptera: Leptophlebiidae: Atalophlebiinae). Zool. J. Linn. Soc-Lond. 126(2):155-189.

DOMÍNGUEZ, E., HUBBARD, M.D. \& PESCADOR, M.L. 1994. Los Ephemeroptera en Argentina. In Fauna de Agua Dulce de la República Argentina (S.A. Castellanos, ed.). FECIC, Buenos Aires, 33(1):1-142.

DOMÍNGUEZ, E., PETERS, W.L., PETERS, J. \& SAVAGE, H.M. 1997. The imago of Simothraulopsis Demoulin with a redescription of the nymph (Ephemeroptera: Leptophlebiidae: Atalophlebiinae). Aquatic Insects, 19(3):141-150. http://dx.doi.org/10.1080/01650429709361648

DOMÍNGUEZ, E., HUBBARD, M.D., PESCADOR, M.L. \& MOLINERI, C. 2001. Ephemeroptera. In Guía para la Determinación de los Artrópodos Bentónicos Sudamericanos (H.R. Fernandez \& E. Domínguez, eds.). Editorial Universitaria de Tucumán, Tucumán, 1:17-53.

DOMÍNGUEZ, E., MOLINERI, C., PESCADOR, M.L., HUBBARD, M.D. \& NIETO, C. 2006. Ephemeroptera of South America. In Aquatic Biodiversity of Latin America (J. Adis, J.R. Arias, G. Rueda-Delgado \& K.M. Wantzen, eds.). Pensoft, Sofia-Moscow, 2:1-646.

Empresa Brasileira de Pesquisa Agropecuária - EMBRAPA. 2004. Solos do Estado de Santa Catarina. In Boletim de Pesquisa e Desenvolvimento (Potter R.O., Carvalho A.P., Flores C.A. \& Bognola I., eds.). Embrapa Solos, Rio de Janeiro, v.46, p.1-728.

FERREIRA JUNIOR, O. 2008. GPS Track Maker.

HIJMANS, R.J., GUARINO, L., BUSSINK, C., MATHUR, P., CRUZ, M., BARRENTES, I., ROJAS, E. 2005. DIVA-GIS: A geographic information system for the analysis of species distribution data. versão 5.2. http:// www.diva-gis.org (last access at 11/05/2013).

FLOWERS, R.W. 2009. A new species of Thraulodes (Ephemeroptera: Leptophlebiidae, Atalophlebiinae) from a highly altered river in western Ecuador. Zootaxa 2052:55-61.

GOULART, M. \& CALLISTO, M. 2005. Mayfly distributions along a longitudinal gradient in Serra do Cipó, southeastern Brazil. Acta Limnol. Bras. 17(1):1-13.

INSTITUTO BRASILEIRO DE GEOGRAFIA E ESTATÍSTICA - IBGE. 2002. Mapa de clima do Brasil.
KLEIN, R. 1978. Mapa fitogeográfico do estado de Santa Catarina. Herbário Barbosa Rodrigues, Itajaí.

LIMA, L.R.C., SALLES, F.F. \& PINHEIRO, U. 2012. Ephemeroptera (Insecta) from Pernambuco State, northeastern Brazil. Rev. Bras. Entomol. 56(3): 304-314. http://dx.doi.org/10.1590/S0085-56262012005000043

LIMA, L.R.C., MARIANO, R. \& PINHEIRO, U.S. 2013. New species for Thraulodes Ulmer, 1920 (Ephemeroptera: Leptophlebiidae: Atalophlebiinae) and the first key to adults from Brazil. Zootaxa. 3709(3):230-242. http://dx.doi.org/10.11646/zootaxa.3709.3.2

LOPES, M.J.N.; RIBEIRO, J.M.F. \& PEIRO, D.F. 2007. Leptophlebiidae (Ephemeroptera) da Amazônia brasileira. Acta Amaz. 37(1):139145. http://www.scielo.br/pdf/ aa/v37n1/v37n1a18.pdf (last access at 01/30/2012).

MARENZI, R.C., FRIGO, F., ECCEL, R. \& SCHIMIDT, A.D. 2005. Unidades de Conservação de Santa Catarina: Base preliminar de um diagnóstico de situação. In III Simpósio de Áreas Protegidas, 2005, Pelotas. Universidade Católica de Pelotas, v.1, p.26-34.

PESCADOR, M.L. \& PETERS, W.L. 1990. Biosystematics of the genus Massartella Lestage (Ephemeroptera: Leptophlebiidae: Atalophlebiinae) from South America. Aquat. Insect. 12(3):145-160. http://dx.doi. org/10.1080/01650429009361399

PETERS, W.L. 1969. Askola froehlichi, a new genus and species from southern Brazil (Leptophlebiidae: Ephemeroptera). Fla. Entomol. 52(4):253-258. http://dx.doi.org/10.2307/3493877

PROGRAMA DAS NAÇÕES UNIDAS PARA O DESENVOLVIMENTO - PNUD, INSTITUTO DE PESQUISA ECONÔMICA APLICADA - IPEA \& FUNDAÇÃO JOÃO PINHEIRO - FJP. 2003. Atlas do Desenvolvimento Humano. PNUD Brasil. http://www.pnud.org.br/atlas (last access at 12/12/2012).

Righi-CAVAllaro, K.O., SIEGLOCH, A.E., CALHEIROS, D. \& BARBOSA, D.S. 2008. Segesta riograndensis, Ephemeroptera, Leptophlebiidae, Atalophlebiinae: first record from state of Mato Grosso do Sul, western Brazil. Check List. 4(4):472-474.

SALLES, F.F., SILVA, E.R., HUBBARD, M.D. \& SERRÃO, J.E. 2004. As espécies de Ephemeroptera (Insecta) registradas para o Brasil. Biota Neotrop. 4(2): http://www.biotaneotropica.org.br/v4n2/pt/abstract?i nventory+BN04004022004 (last access at 06/23/2011).

SALLES, F.F. 2006. A ordem Ephemeroptera (Insecta) no Brasil: diversidade e taxonomia. Tese de Doutorado, Universidade Federal de Viçosa, Minas Gerais.

SALLES, F.F., CAVALCANTE DO NASCIMENTO J.M., MASSARIOL, F.C., ANGELI, K.B., BARCELOS E SILVA P., RÚDIO, J.A. \& BOLDRINI, R. 2010. Primeiro levantamento da fauna de Ephemeroptera (Insecta) do Espírito Santo, Sudeste do Brasil. Biota Neotrop. 10(1): $\mathrm{http} / / /$ www.biotaneotropica.org.br/v10n1/pt/ download?inventory+bn0 2610012010+item (last access at 10/16/2011).

SALLES, F.F. \& DOMÍNGUEZ, E. 2012. Systematics and Phylogeny of Ulmeritus-Ulmeritoides revisited (Ephemeroptera: Leptophlebiidae). Zootaxa 3571: 49-65.

SALLES, F.F., BOLDRINI, R., NASCIMENTO, J.M.C., ANGELI, K.B., MASSARIOL, F.C., RAIMUNDI E. 2013. Ephemeroptera do Brasil. http://ephemeroptera.com.br/ (last access at 09/12/2013).

SANTA CATARINA. 1998. Secretaria de Estado do Desenvolvimento Econômico Sustentável. Lei $\mathrm{n}^{\circ} 10.949$, de 09 de novembro de 1998. Dispõe sobre a caracterização do Estado em 10 (dez) Regiões Hidrográficas, Florianópolis.

SHIMANO, Y., SALLES, F.F. \& CABETTE, H.S.R. 2011. Ephemeroptera (Insecta) from east of Mato Grosso State, Brazil. http://www. biotaneotropica.org.br/v11n4/pt/fullpaper?bn020110 42011+pt(last access at 09/21/2013).

SHIMANO, Y., SALLES, F.F., FARIA, L.R.R., CABETTE, H.S.R. \& NOGUEIRA, D. 2012. Distribuição espacial das guildas tróficas e estruturação da comunidade de Ephemeroptera (Insecta) em córregos do 
Cerrado de Mato Grosso, Brasil. Iheringia, Ser. Zool., 102(2):187-196. http://dx.doi.org/10.1590/S0073-47212012000200011

SHIMANO, Y., JUEN, L., NOGUEIRA, D.S., CABETTE, H.S.R. \& SALLES, F.F. 2013. Environmental and spatial processes determining Ephemeroptera (Insecta) structures in tropical streams. Ann. Limnol., 49:31-41. http://dx.doi.org/10.1051/limn/2013036

SIEGLOCH, A.E., FROEHLICH, C.G. \& KOTZIAN, C.B. 2008. Composition and diversity of Ephemeroptera (Insecta) nymph communities in the middle section of the Jacuí River and some tributaries, southern Brazil. Iheringia, Sér. Zool. 98(4):425-432. http://www.scielo.br/pdf/isz/v98n4/ v98n04a02.pdf (last access at 06/15/2009).

SOS MATA ATLÂNTICA \& INSTITUTO NACIONAL DE PESQUISAS ESPACIAIS - INPE. 2009. Atlas dos remanescentes florestais da Mata Atlântica, período de 2005 a 2008. São Paulo.

SPESSATTO, M.B. 2001. O diário de Fritz Plaumann. Argos, Chapecó.
TABARELLI, M., PINTO, L.P., SILVA, J.M.C., HIROTA, M. \& BEDÊ, L. 2005. Desafios e oportunidades para a conservação da biodiversidade na Mata Atlântica brasileira. Megadiversidade 1:132-138.

TESTA, V.M., NADAL, R., MIOR, L.C., BALDISSERA, I.T. \& CORTINA, N.O. 1996. Desenvolvimento Sustentável do Oeste Catarinense: proposta para discussão. Epagri, Florianópolis.

THEW, T.B. 1960. Taxonomic studies on some Neotropical Leptophlebiid mayflies (Ephemeroptera: Leptophlebiidae). Pan-Pac Entomol., 36(3):119-132.

TSUI, P.T.P. \& PETERS, W.L. 1975. The Comparative Morphology and Phylogeny of Certain Gondwanian Leptophlebiidae Based on the Thorax, Tentorium, and Abdominal Terga (Ephemeroptera). T. Am. Entomol. Soc. 101(4):505-595.

ULMER, G. 1920. Neue Ephemeropteren. Arch. Naturg. 85(11):1-80.

WOLLF, J.N. \& SCHUH, M.B. 2000. Memória e experiência. Argos, Chapecó. 
Raimundi, E.A. et al.

Appendix 1. Localization of aquatic environments sampled in west region of Santa Catarina presenting the name of each site, and geographic coordinates.

\begin{tabular}{|c|c|c|c|c|c|}
\hline Site & Latitude & Longitude & Site & Latitude & Longitude \\
\hline Adami & $26^{\circ} 48^{\prime} 47.3^{\prime \prime} \mathrm{S}$ & $51^{\circ} 48^{\prime} 58.8^{\prime \prime} \mathrm{W}$ & Lajeado São José2 & $27^{\circ} 02^{\prime} 18.0^{\prime \prime} \mathrm{S}$ & $52^{\circ} 38^{\prime} 46.0^{\prime \prime} \mathrm{W}$ \\
\hline Caçador1 & $27^{\circ} 07^{\prime} 53.5^{\prime \prime} \mathrm{S}$ & $52^{\circ} 19^{\prime} 23.7 ” \mathrm{~W}$ & Lajeado São José3 & $27^{\circ} 05^{\prime} 80.0^{\prime \prime} \mathrm{S}$ & $52^{\circ} 39^{\prime} 42.0 ” \mathrm{~W}$ \\
\hline Caçador2 & $27^{\circ} 08^{\prime} 14.4 ” \mathrm{~S}$ & $52^{\circ} 18^{\prime} 35.1^{\prime \prime} \mathrm{W}$ & Lajeado São José4 & $27^{\circ} 07^{\prime} 55.0^{\prime \prime} \mathrm{S}$ & $52^{\circ} 40^{\prime} 45.0 ” \mathrm{~W}$ \\
\hline Caramuru & $27^{\circ} 05^{\prime} 20.8^{\prime \prime} \mathrm{S}$ & $52^{\circ} 39^{\prime} 59.3 ” \mathrm{~W}$ & Lajeado São José5 & $27^{\circ} 07^{\prime} 21.3^{\prime \prime} \mathrm{S}$ & $52^{\circ} 40^{\prime} 24.3^{\prime \prime} \mathrm{W}$ \\
\hline Caratuva & $26^{\circ} 50^{\prime} 23.9^{\prime \prime} \mathrm{S}$ & $51^{\circ} 59^{\prime} 15.6 ” \mathrm{~W}$ & Lambedor1 & $27^{\circ} 01 ' 35.5^{\prime} \mathrm{S}$ & $52^{\circ} 48^{\prime} 33.1^{\prime \prime} \mathrm{W}$ \\
\hline Chapecó1 & $26^{\circ} 41^{\prime} 31.5^{\prime \prime} \mathrm{S}$ & $51^{\circ} 56^{\prime} 06.6 ” \mathrm{~W}$ & Lambedor2 & $27^{\circ} 08^{\prime} 89.0 ” \mathrm{~S}$ & $52^{\circ} 50^{\prime} 67.0 ” \mathrm{~W}$ \\
\hline Chapecó2 & $26^{\circ} 53^{\prime} 26.1 ” \mathrm{~S}$ & $52^{\circ} 49^{\prime} 17.2^{\prime \prime} \mathrm{W}$ & Marconstrói & $26^{\circ} 45^{\prime} 43.8^{\prime \prime} \mathrm{S}$ & $51^{\circ} 57^{\prime} 28.8^{\prime \prime} \mathrm{W}$ \\
\hline Chapecó3 & $27^{\circ} 05^{\prime} 51.1 " \mathrm{~S}$ & $53^{\circ} 0 ’ 25.06^{\prime \prime} \mathrm{W}$ & Mato1 & $26^{\circ} 48^{\prime} 48.1^{\prime \prime} \mathrm{S}$ & $51^{\circ} 54^{\prime} 07.9$ ” W \\
\hline Chapecó4 & $26^{\circ} 36^{\prime} 03.6^{\prime \prime} \mathrm{S}$ & $52^{\circ} 29^{\prime} 03.7^{\prime \prime} \mathrm{W}$ & Mato2 & $26^{\circ} 48^{\prime} 46.3^{\prime \prime} \mathrm{S}$ & $51^{\circ} 54^{\prime} 09.3^{\prime \prime} \mathrm{W}$ \\
\hline Chapecó5 & $26^{\circ} 39^{\prime} 07.4 ” \mathrm{~S}$ & $52^{\circ} 32^{\prime} 02.4^{\prime \prime} \mathrm{W}$ & Monte Alegre & $27^{\circ} 14^{\prime} 33.1^{\prime \prime} \mathrm{S}$ & $52^{\circ} 35^{\prime} 19.8^{\prime \prime} \mathrm{W}$ \\
\hline Chapecozinho1 & $26^{\circ} 46^{\prime} 01.6^{\prime \prime} \mathrm{S}$ & $51^{\circ} 49^{\prime} 49.8^{\prime \prime} \mathrm{W}$ & Palmitos 1 & $27^{\circ} 03$ '04.6” S & $53^{\circ} 09^{\prime} 44.8^{\prime \prime} \mathrm{W}$ \\
\hline Chapecozinho2 & $26^{\circ} 46^{\prime} 48.2^{\prime \prime} \mathrm{S}$ & $51^{\circ} 58^{\prime} 48.2^{\prime \prime} \mathrm{W}$ & Palmitos2 & $27^{\circ} 09^{\prime} 33.5^{\prime \prime} \mathrm{S}$ & $53^{\circ} 08^{\prime} 37.0 ” \mathrm{~W}$ \\
\hline Iracema 1 & $26^{\circ} 42^{\prime} 53.0 ” \mathrm{~S}$ & $53^{\circ} 09^{\prime} 38.9^{\prime \prime} \mathrm{W}$ & Pitoco1 & $27^{\circ} 14^{\prime} 23.2^{\prime \prime} \mathrm{S}$ & $52^{\circ} 38^{\prime} 35.9^{\prime \prime} \mathrm{W}$ \\
\hline Iracema2 & $26^{\circ} 50^{\prime} 01.5^{\prime \prime} \mathrm{S}$ & $53^{\circ} 14^{\prime} 35.9^{\prime \prime} \mathrm{W}$ & Pitoco 2 & $27^{\circ} 14^{\prime} 21.2 ” \mathrm{~S}$ & $52^{\circ} 38^{\prime} 35.9^{\prime \prime} \mathrm{W}$ \\
\hline Iracema3 & $27^{\circ} 03$ ' $48.6^{\prime \prime} \mathrm{S}$ & $53^{\circ} 17^{\prime} 21.1^{\prime \prime} \mathrm{W}$ & SantaFé & $27^{\circ} 09^{\prime} 21.1 ” \mathrm{~S}$ & $53^{\circ} 41^{\prime} 15.8^{\prime \prime} \mathrm{W}$ \\
\hline Irani1 & $26^{\circ} 55^{\prime} 50.8^{\prime \prime} \mathrm{S}$ & $51^{\circ} 41^{\prime} 03.8^{\prime \prime} \mathrm{W}$ & Santo Antônio dos Pinhais & $26^{\circ} 50^{\prime} 38.7^{\prime \prime} \mathrm{S}$ & $52^{\circ} 49^{\prime} 11.6^{\prime \prime} \mathrm{W}$ \\
\hline Irani2 & $26^{\circ} 55^{\prime} 49.9^{\prime \prime} \mathrm{S}$ & $51^{\circ} 52^{\prime} 29.6 ” \mathrm{~W}$ & São Domingos1 & $26^{\circ} 50^{\prime} 05.4^{\prime \prime} \mathrm{S}$ & $53^{\circ} 11^{\prime} 16.2^{\prime \prime} \mathrm{W}$ \\
\hline Irani3 & $26^{\circ} 57^{\prime} 05.1{ }^{\prime \prime} \mathrm{S}$ & $52^{\circ} 17^{\prime} 08.1 ” \mathrm{~W}$ & São Domingos2 & $26^{\circ} 53^{\prime} 25.3 ” S$ & $53^{\circ} 10^{\prime} 51.8^{\prime \prime} \mathrm{W}$ \\
\hline Irani4 & $26^{\circ} 57^{\prime} 09.3 ” S$ & $52^{\circ} 18^{\prime} 07.2^{\prime \prime} \mathrm{W}$ & São Domingos3 & $27^{\circ} 04^{\prime} 25.9^{\prime \prime} \mathrm{S}$ & $53^{\circ} 14^{\prime} 02.7^{\prime \prime} \mathrm{W}$ \\
\hline Irani5 & $26^{\circ} 55^{\prime} 09.9^{\prime \prime} \mathrm{S}$ & $51^{\circ} 52^{\prime} 29.6^{\prime \prime} \mathrm{W}$ & Sede1 & $26^{\circ} 43^{\prime} 22.7 ” \mathrm{~S}$ & $51^{\circ} 51^{\prime} 44.4^{\prime \prime} \mathrm{W}$ \\
\hline Irani6 & $26^{\circ} 58^{\prime} 01.1 ” \mathrm{~S}$ & $52^{\circ} 19^{\prime} 05.5^{\prime \prime} \mathrm{W}$ & Sede2 & $26^{\circ} 43^{\prime} 25.8^{\prime \prime} \mathrm{S}$ & $51^{\circ} 51^{\prime} 46.2^{\prime \prime} \mathrm{W}$ \\
\hline Irani7 & $26^{\circ} 57^{\prime} 28.0^{\prime \prime} \mathrm{S}$ & $52^{\circ} 20^{\prime} 25.0 ” \mathrm{~W}$ & Taquaruçú1 & $26^{\circ} 58^{\prime} 29.4 ” \mathrm{~S}$ & $52^{\circ} 36^{\prime} 11.0 ” \mathrm{~W}$ \\
\hline Irani8 & $26^{\circ} 58^{\prime} 02.4^{\prime \prime} \mathrm{S}$ & $52^{\circ} 21^{\prime} 07.6^{\prime \prime} \mathrm{W}$ & Taquaruçú2 & $26^{\circ} 54^{\prime} 33.8^{\prime \prime} \mathrm{S}$ & $52^{\circ} 41^{\prime} 26.4^{\prime \prime} \mathrm{W}$ \\
\hline Irani9 & $27^{\circ} 00^{\prime} 08.0^{\prime \prime} \mathrm{S}$ & $52^{\circ} 25^{\prime} 06.2^{\prime \prime} \mathrm{W}$ & Tarumã1 & $26^{\circ} 54^{\prime} 21.1 ” \mathrm{~S}$ & $52^{\circ} 45^{\prime} 22.9^{\prime \prime} \mathrm{W}$ \\
\hline Irani10 & $27^{\circ} 01^{\prime} 08.3 ” \mathrm{~S}$ & $52^{\circ} 26^{\prime} 00.0 ” \mathrm{~W}$ & Tarumã2 & $26^{\circ} 53 ’ 48.1 ” S$ & $52^{\circ} 48^{\prime} 41.8^{\prime \prime} \mathrm{W}$ \\
\hline Irani11 & $27^{\circ} 05^{\prime} 17.4 ” \mathrm{~S}$ & $52^{\circ} 29^{\prime} 14.2^{\prime \prime} \mathrm{W}$ & Tarumã3 & $26^{\circ} 56^{\prime} 23.0^{\prime \prime} \mathrm{S}$ & $52^{\circ} 48^{\prime} 05.8^{\prime \prime} \mathrm{W}$ \\
\hline Irani12 & $27^{\circ} 14^{\prime} 00.5^{\prime \prime} \mathrm{S}$ & $52^{\circ} 32^{\prime} 28.4^{\prime \prime} \mathrm{W}$ & Tigre & $27^{\circ} 05^{\prime} 27.1 ” \mathrm{~S}$ & $52^{\circ} 47^{\prime} 00.4^{\prime \prime} \mathrm{W}$ \\
\hline Lajeado Bonito1 & $27^{\circ} 02^{\prime} 33.8^{\prime \prime} \mathrm{S}$ & $52^{\circ} 51^{\prime} 51.9^{\prime \prime} \mathrm{W}$ & Vargem Bonita1 & $26^{\circ} 53$ ' 41.0” S & $51^{\circ} 42^{\prime} 12.0^{\prime \prime} \mathrm{W}$ \\
\hline Lajeado Bonito2 & $27^{\circ} 06^{\prime} 49.5^{\prime \prime} \mathrm{S}$ & $52^{\circ} 57^{\prime} 33.5^{\prime \prime} \mathrm{W}$ & Vargem Bonita2 & $26^{\circ} 53$ ' 42.0” S & $51^{\circ} 42^{\prime} 13.0^{\prime \prime} \mathrm{W}$ \\
\hline Lajeado Divisa & $27^{\circ} 10^{\prime} 53.1 ” \mathrm{~S}$ & $52^{\circ} 36^{\prime} 30.4^{\prime \prime} \mathrm{W}$ & Xaxim & $26^{\circ} 52^{\prime} 07.1 ” \mathrm{~S}$ & $52^{\circ} 43^{\prime} 31.8^{\prime \prime} \mathrm{W}$ \\
\hline Lajeado São José1 & $27^{\circ} 00^{\prime} 10.0 ” \mathrm{~S}$ & $52^{\circ} 37^{\prime} 51.0 ” \mathrm{~W}$ & & & \\
\hline
\end{tabular}

